GIULIANO SAVIOLI DELIBERADOR

\title{
FUNDAMENTOS JURÍDICOS DA COOPERAÇÃO FEDERATIVA EM MATÉRIA DE RECURSOS HÍDRICOS
}

Tese de Doutorado

Orientadora: Profa. Associada Dra. Monica Herman Salem Caggiano

UNIVERSIDADE DE SÃO PAULO

FACULDADE DE DIREITO

SÃO PAULO

2016 
GIULIANO SAVIOLI DELIBERADOR

\section{FUNDAMENTOS JURÍDICOS DA COOPERAÇÃO FEDERATIVA EM MATÉRIA DE RECURSOS HÍDRICOS}

Tese apresentada à Banca Examinadora do Programa de Pós-Graduação em Direito da Faculdade de Direito da Universidade de São Paulo como exigência parcial para obtenção do título de Doutor em Direito, na área de concentração de Direito do Estado, sob orientação da Profa. Associada Doutora Monica Herman Salem Caggiano.

UNIVERSIDADE DE SÃO PAULO

FACULDADE DE DIREITO

SÃO PAULO

2016 
Deliberador, Giuliano savioli

Fundamentos jurídicos da cooperação federativa em matéria de recursos hídricos/Giuliano savioli Deliberador ; orientadora Monica Herman salem Caggiano -- São Paulo, 2016. 152

Tese (Doutorado - Programa de Pós-Graduação em Direito do Estado) - Faculdade de Direito, Universidade de são Paulo, 2016.

1. Federalismo. 2. Recursos hídricos. 3. Direito de águas. I. Caggiano, Monica Herman Salem, orient. II. Título. 


\section{AGRADECIMENTOS}

Qualquer trabalho de conclusão de curso, como o próprio nome já evidencia, representa o final de um ciclo. Porém, nenhum outro o faz como uma tese de doutorado. Ela é o ápice de uma trajetória que começa, na minha visão, com a alfabetização. Ter chegado até aqui é um privilégio, e definitivamente isso não teria sido possível sem ajuda de muita gente. Impossível será lembrar de todos, e pelos esquecimentos peço antecipadas desculpas. Em todo caso, vamos lá.

Em primeiro lugar, à minha família, minha verdadeira fortaleza. Meus avós, sempre amorosos; meu pai, forte e ponderado; minha mãe, afetuosa e generosa; minha irmã, o tempo todo me lembrando do real significado das coisas; e meu cunhado, que sempre sabe se a carne está no ponto, porque não há angústia acadêmica que não se resolva num churrasco. À Isabel, que mineiramente chegou na minha vida e mudou completamente o significado de tudo, apresentando um mundo de sensações que eu julgava não existirem fora da ficção e da arte. Amo vocês todos.

Aos professores que tive na vida, que me apresentaram ao mundo do conhecimento. Citando a primeira, a Professora Marisa Cândido Paulino, responsável pela minha alfabetização. Desde 1989, a cada palavra que escrevo ou leio, devo a ela um sincero agradecimento, pelo afeto e sensibilidade que marcaram minha vida. E, é claro, à minha dileta orientadora, Profa. Associada Doutora Monica Herman Salem Caggiano, intelectual extraordinária, cujo legado acadêmico perdurará por décadas no estudo dos mais espinhosos do direito constitucional brasileiro. Acompanhando-a desde que fui seu aluno de graduação, em 2005, não encontrei ainda questão para a qual não tivesse uma resposta tão simples quanto brilhante. É e sempre será a referência acadêmica mais significativa da minha vida. Privilegiados somos os seus discípulos.

Por fim, aos amigos que a Faculdade de Direito me proporcionou, mostrando que é realmente no Largo São Francisco, na Velha Academia, que moram a amizade e a alegria. Ana Paula Fuliaro, pessoa incrível que faz você se sentir bem e confortável em qualquer situação; Ana Luiza Cipriano, parceira de infinitas monitorias; Vivian Grégori, cujo afeto não tem limites; Daniel Falcão, cujo brilhantismo só encontra parâmetro na sua generosidade. À Ana Carolina Albuquerque, minha anfitriã em Brasília, mais uma fantástica professora que o Largo São Francisco produziu. Emanuel Pessoa, com seu eterno bom humor, que não eclipsa seu refinamento intelectual. Ao Zé Antônio Apparecido, pelas memoráveis discussões que misturam futebol e direito urbanístico com total naturalidade, sob o amálgama da cerveja. Ao Fernando Couto, dono de um papo bom como um pão de queijo. Ao Alexandre Jorge, à Ana Rita Nery, à Isabela Meloncini, grandes pessoas, amigos fraternos. E a todos os Inquilinos, em particular ao Luiz Dellore, brilhante professor, amigo gregário, alguém que sabe como poucos reunir pessoas sob a luz da amizade.

Definitivamente, sou um privilegiado. 
Este trabalho é dedicado a Sérgio, Dilma, Hélio, Márcia, Marcella, André e mais alguém que qualquer hora aparece por aqui. E, em especial, à minha amada Bel. 
"O rio de Piracicaba vai jogar água pra fora quando chegar a água dos olhos de alguém que chora." Rio de Lágrimas

Lourival dos Santos (letra) Tião Carreiro e Piraci (música) 1970 


\section{RESUMO}

Este trabalho tem por finalidade investigar a incidência do dever de cooperação derivado do princípio da lealdade federativa, conhecido no direito alemão como bundestreue, à gestão dos recursos hídricos. Para isso, examina as principais características do federalismo, os diferentes modelos através dos quais se apresentou ao longo do tempo no Brasil e no direito comparado (federalismo clássico- dual-, de integração e cooperativo). A partir disso, busca compreender o surgimento, os fundamentos e o âmbito de aplicação do princípio da lealdade federativa no direito alemão e brasileiro, concluindo pela incorporação de referida norma pelo Constituinte originário de 1988. Em seguida, passa a examinar o regramento jurídico do uso da água, analisando os principais sistemas existentes no direito comparado. Chega então ao estudo da maneira como o tema foi tratado nas Constituições brasileiras desde o Império até os dias atuais, com especial destaque para a Constituição Federal de 1988, para então perquirir o regime infraconstitucional do direito de águas no Brasil. Por fim, conclui tratar-se a gestão de recursos hídricos de uma competência comum a todos os entes federados, devendo ser exercida sob os parâmetros de cooperação desenvolvidos sob a guarda do princípio do bundestreue.

Palavras chave: Federalismo, gerenciamento de recursos hídricos, lealdade federativa

DELIBERADOR, Giuliano Savioli. Fundamentos da cooperação federativa em matéria de recursos hídricos. 2016. 152 p. Doutorado em Direito- Faculdade de Direito, Universidade de São Paulo, 2016. 


\section{SUMMARY}

The purpose of this dissertation is to analyze the water resources management in light of the cooperation duty derived from the principle of federative loyalty (known in German law as bundestreue principle). First, it will examine the main characteristics of federalism and the different models that it has appeared over time in Brazil and abroad (classical/dual, integration and cooperative federalism). After that, it will present the reasons concerning the creation and the main scopes of the federative loyalty principle both in German and Brazilian law, including the adoption of this principle by the Brazilian Constitution enacted in 1988. Then, it goes on to examine legislation concerning the use of water resources around the world, investigating the main systems developed in this area, including prior appropriation and riparianism. Subsequently, it will present a study on how this field was treated historically in Brazilian Constitutions from the Empire times to the present day, with special emphasis on the Federal Constitution of 1988. It will also assess the legal regime of water statues in Brazil. Finally, it concludes that water resources management is a common responsibility of all federal entities and should be carried out under the parameters of cooperation developed under the bundestreue principle.

Keywords: federalism, water resources management, federal loyalty.

DELIBERADOR, Giuliano Savioli. Legal basis for federative cooperation in the field of water resources. 2016. 152 p. Doctorate in Law- Faculty of Law, University of São Paulo, 2016. 


\section{RÉSUMÉ}

Cette étude vise à étudier l'incidence du devoir de coopération secondaire du principe de loyauté fédérale, connue dans le droit allemand en tant bundestreue, la gestion des ressources en eau. Pour cela, il examine les principales caractéristiques du fédéralisme, les différents modèles qui sont apparus au fil du temps au Brésil et en droit comparé (fédéralisme duale, d'intégration et de coopération). De là, cherche à comprendre l'apparence, les motifs et la portée du principe de loyauté fédérale en droit allemand et brésilien, complétant avec l'incorporation de cette norme par la Constitution Brésilien de 1988. Il passe ensuite a examiner les principaux systèmes du droit de l'eau existants en droit comparé. Il étude la façon dont le droit de l'eau a été traité dans les constitutions brésiliennes, de l'Empire à nos jours, avec un accent particulier sur la Constitution Fédérale de 1988 et cherche le régime infraconstitutionnelle du droit de l'eau au Brésil. Enfin, il conclut qu'il la gestion des l'eau est une responsabilité commune à tous les organismes fédéraux, doit être exercé dans les paramètres de coopération développés sous le principe de la bundestreue.

Mots-clés: fédéralisme, gestion des ressources en eau, loyauté fédérale.

DELIBERADOR, Giuliano Savioli. Fondements juridiques de la coopération fédératif dans le domaine des ressources en eau. 2016. 152 p. Doctorate en DroitFaculté de Droit, Université de São Paulo, 2016. 


\section{LISTA DE FIGURAS}

FIGURA 1: Vazões de retirada totais (captada e consumida) no Brasil (m³/s)

FIGURA 2: Outorgas de recursos hídricos para uso industrial

FIGURA 3: Matriz energética brasileira (Dez. 2014)

FIGURA 4: Vazões médias e disponibilidade hídrica anual por habitante nas macrobacias brasileiras

FIGURA 5: Estados Unidos: modelos de regulação do uso de recursos hídricos 


\section{SUMÁRIO}

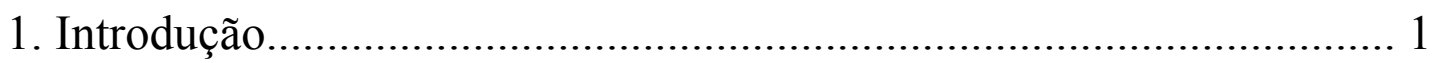

1.1. Pressupostos metodológicos................................................ 1

1.2. Os recursos hídricos e o Brasil atual: considerações

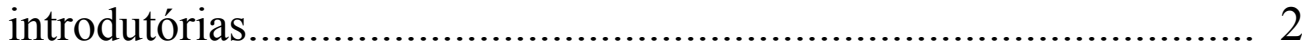

2. Formas de Estado: Federalismo e outras Tipologias Estatais............ 14

2.1. Tipologias Estatais: O Estado Unitário e a antítese do

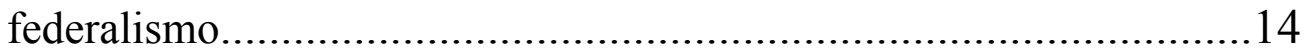

2.2. Tipologias Estatais: o Estado Autonômico Espa-

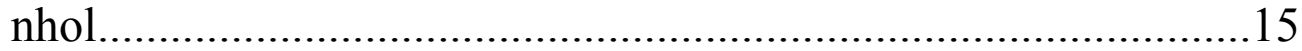

2.3. Tipologias Estatais: O Estado Regional Italiano................... 18

2.4. O Estado Federal: fundamentos e principais elementos....... 22

2.4.1. Os elementos da autonomia dos entes federados e o

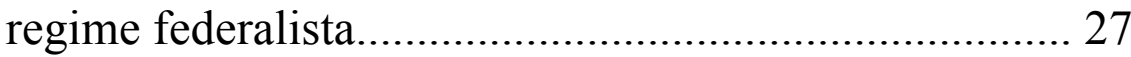

2.5. Modelos de federalismo ....................................................... 41

2.6. A cooperação no federalismo cooperativo............................. 51

2.7. O Princípio da Lealdade Federativa (Bundestreue): origens, fundamentos e implicações....................................................... 53

3. O tratamento jurídico da água no Brasil e no estrangeiro.................... 66

3.1. Modelos de regulação: a doutrina da apropriação primária.. 71

3.2. Modelos de regulação: a doutrina do "riparianismo"........... 83

3.3. O direito de águas e o constitucionalismo brasileiro............ 90

3.4. O regramento infraconstitucional do direito de águas........ 100

3.5. O exercício da função administrativa e o controle do uso dos recursos hídricos no direito brasileiro ........................................112

4. Cooperação federativa e gestão de recursos hídricos.........................125

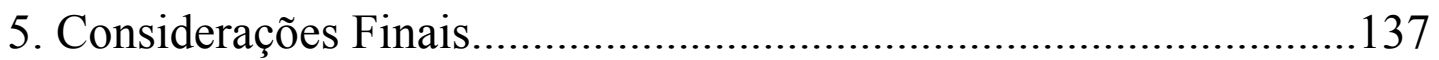

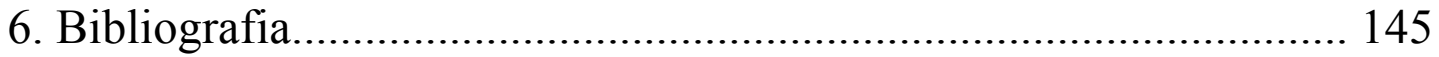




\section{FUNDAMENTOS JURÍDICOS DA COOPERAÇÃO FEDERATIVA EM MATÉRIA DE RECURSOS HÍDRICOS}

\section{INTRODUÇÃO \\ 1.1 Pressupostos metodológicos}

Ao se executar um projeto de pesquisa, faz-se necessária uma reflexão fundamental: quais serão as bases metodológicas que darão sustentação ao trabalho? As alternativas são sempre muitas, ainda que se trate, como é o caso aqui, de um trabalho afeito a uma ciência social aplicada, como é o Direito. Em outras palavras, temos que, se o tema escolhido e o objetivo estabelecido representam o destino a que se quer chegar, e a pesquisa é o caminho a ser percorrido, a metodologia empregada é o meio de transporte empregado para tanto.

Uma vez mais, a escolha da metodologia é quase uma decorrência do tema eleito para o trabalho: a análise documental. Isso porque as fontes disponíveis para este tipo de estudo são exclusivamente documentais. Portanto, esta pesquisa englobará a análise de duas classes de fontes: as primárias, ou seja, aqueles dados originais, isentos de qualquer análise anterior, e as secundárias, que são aquelas que já foram objeto de algum tipo de pesquisa, incorporadas, portanto, ao domínio científico. Importante anotar que por fonte primária aqui se entende o texto bruto tanto de normas, quer sejam extraídas da Constituição ou da Legislação Infra-Constitucional, e de julgados, principalmente dos Tribunais Superiores, em particular do Supremo Tribunal Federal.

Fundamental assinalar também que, dada a atual condição de interdependência entre os diversos países do mundo, não pode qualquer estudo sério se furtar de empreender um estudo de direito comparado. O estudo do tratamento dado ao tema no direito estrangeiro é de fundamental importância, pois oferece elementos muito úteis ao cientista, já que vivemos hoje um movimento de franca expansão do direito comparado, até pelas exigências de harmonização do direito entre os diferentes ordenamentos, que obriga o analista a não descuidar da busca e análise do tratamento dado ao seu objeto de estudo pelo direito em outros países. Nesse sentido, aliás, caminha a lição da Professora Ana Lúcia de Lyra Tavares ${ }^{1}$.

\footnotetext{
${ }^{1}$ TAVARES, Ana Lúcia de Lyra. Contribuição do Direito Comparado às fontes do Direito Brasileiro. Prisma
} 


\subsection{Os recursos hídricos e o Brasil atual: considerações introdutórias}

A República Federativa do Brasil, como o próprio nome mostra, organiza-se sob a forma federativa de Estado. É formada, nos termos do art. $1^{\circ}$ da Constituição Federal, pela união indissolúvel dos Estados, Municípios e do Distrito Federal.

Assim, no Brasil o poder político é exercido através da divisão de uma série de encargos, rendas e atribuições entre pessoas políticas distribuídas entre três níveis de governo, em nível local (Municípios), regional (Estados e Distrito Federal) e nacional (União).

Dentre essas atribuições e encargos, destacam-se aquelas relacionadas à gestão do recurso natural mais precioso: a água. A água é condição para a própria vida, e fator de produção obrigatório em qualquer cadeia produtiva. Isso passa a exigir do Estado um cuidado extraordinário na gestão desse bem finito e fundamental para a vida digna e saudável, para o crescimento econômico e para um meio ambiente equilibrado.

Nesse contexto assume particular relevo a discussão sobre a forma como se dividem as competências em matéria de recursos hídricos ${ }^{2}$ sob o marco da Constituição Federal. E mais do que isso, a forma como os três níveis de governo cooperam (ou pelo menos deveriam cooperar) para promover uma gestão racional da água, que permita a todos o acesso a ela ao mesmo tempo em que seja garantida a sua preservação para as futuras gerações.

Os dilemas federativos atuais no Brasil se exacerbam quando o assunto é a gestão dos recursos hídricos. A crise porque recentemente passaram diversas unidades da federação no que toca a oferta de água para abastecimento público, irrigação, uso industrial, produção de energia, particularmente grave na região Sudeste, ensejou conflitos diversos entre os diversos atores do Sistema Nacional de Gestão de Recursos Hídricos, quer seja entre bacias hidrográficas cujas águas são transpostas para atendimento da demanda de outras bacias, como ocorre no Estado de São Paulo através do Sistema Cantareira, quer seja entre áreas a montante e a jusante de determinados corpos d'água,

\footnotetext{
${ }^{2}$ A literatura técnica aponta que a expressão "recurso hídrico" significa água vista sob a perspectiva do reconhecimento de seu valor econômico, em oposição à sua condição natural. Nesse estudo, pode-se tomar água e recursos hídricos como expressões sinônimas.
} 
muitas vezes envolvendo acirradas discussões entre Estados distintos, como aconteceu na Ação Cível Originária (ACO) 2536, que entre 2014 e 2016 tramitou junto ao Excelso Pretório, na qual litigaram o Ministério Público Federal contra os Estados de São Paulo, Minas Gerais e Rio de Janeiro, mais a União Federal, o IBAMA e a Agência Nacional de Águas (ANA), tendo por objeto a transposição de águas da bacia hidrográfica do Paraíba do Sul para as bacias dos rios Piracicaba, Capivari e Jundiaí.

Um dado relevante a ser levantado é que este conflito não foi, em momento algum, levado aos órgãos do Sistema Nacional de Gestão dos Recursos Hídricos, em particular o Conselho Nacional de Recursos Hídricos, tendo sido imediatamente judicializado, o que levanta questionamentos importantes acerca da eficácia dos meios extrajudiciais de composição de conflitos entre os entes federativos em matéria hídrica. Na nossa visão, isso é sintoma de um desenvolvimento incompleto dos mecanismos de cooperação federativa, mesmo porque entendemos que esse conflito não tem, pelo menos primordialmente, conteúdo jurídico, o que afastaria a competência originária do STF (art. 102, I, " $f$ " da Constituição Federal), e mesmo do Poder Judiciário como um todo (se o conflito não tem caráter jurídico, não há lesão potencial ou efetiva a direito, inaplicável o inc. XXXV do art. $5^{\circ}$ da Carta Política) ${ }^{3}$.

Estivessem os referidos mecanismos operando à altura de sua potencialidade, essas "guerras" por vazões outorgáveis certamente não seriam trazidas à atenção do Poder Judiciário, já açodado por verdadeiras avalanches de demandas. Tanto é assim que o conflito foi resolvido através de técnicas de mediação utilizadas pelo Exmo. Senhor Ministro Luiz Fux, que funcionou como Relator da Ação Cível, que poderiam perfeitamente ter sido aplicadas com o mesmo sucesso fora dos muros do Judiciário.

O cotidiano da gestão dos recursos hídricos no Brasil mostra, portanto, a extrema necessidade de cooperação entre União, Estados e Municípios. No entanto, é forçoso reconhecer que os mecanismos utilizados para isso são frágeis, instáveis e mesmo eletivos, no sentido de que acabam ficando reféns de conveniências político-administrativas que

\footnotetext{
${ }^{3} \mathrm{O}$ pano de fundo que sustenta tal afirmação é que, na realidade, esse conflito versa sobre a alocação de uma determinada vazão, estimada em $5 \mathrm{~m}^{3} / \mathrm{s}$, para o mesmo uso (abastecimento público), mas em diferentes bacias hidrográficas. O conteúdo jurídico do conflito se esgota na exata medida em que os usos em questão são iguais, afastando as regras de priorização da Lei 9.433/97, bem como no fato de que a captação ocorreria em curso d'água de domínio do Estado de São Paulo (rio Jaguari), ainda que tal recurso hídrico deságue, e portanto seja tributário de rio de domínio federal (Paraíba do Sul). Assim, seria juridicamente correto supor que, sendo o rio de domínio estadual paulista, não caberia ao Rio de Janeiro qualquer direito sobre ele, e portanto, sobre suas vazões.
} 
muitas vezes paralisam medidas de suma importância na preservação das águas (a praga das ocupações irregulares de áreas de proteção de mananciais talvez seja o maior exemplo disso, com as suas repercussões locais, regionais e até nacionais em alguns casos).

Diante de um quadro como esse é fundamental que a Academia se debruce sobre o tema. Se a gestão de recursos hídricos é tema comum em Escolas de Geologia, Engenharia e Geografia, lamentavelmente não se pode dizer o mesmo do Direito. São poucos, para não dizer nenhum, os estudos que analisam a gestão da água sob o viés federativo. É o momento de se aprofundar o estudo do direito de águas e, principalmente, de estudar as possibilidades de cooperação federativa em matéria de recursos hídricos. É esse um passo obrigatório para a ciência do Direito, sem o qual ela não estará cumprindo a contento a sua função social, e também para a Faculdade de Direito da Universidade de São Paulo, em nome da preservação de sua tradição bandeirante de contribuir ativamente para a inovação e para o avanço da ciência jurídica brasileira.

Esse quadro de relativo alheamento da Ciência Jurídica ao estudo sobre o tema se torna ainda mais grave quando se percebe a importância da água (e, por consequência. dos recursos hídricos) como condicionante inafastável da dignidade humana. Já tivemos, em ocasião anterior, oportunidade para discutir o caráter transcendental da dignidade humana e sua qualidade de elemento caracterizador de uma prerrogativa de tal importância que possa ser chamada de Direito Fundamental ${ }^{4}$. Com relação ao direito à água, Luiz Alberto David Araújo traz interessante discussão:

“A água faz parte do conteúdo mínimo de dignidade de alguém. Não se pode imaginar o ser humano vivendo sem água. E, sendo assim, o direito à água faz parte de um conteúdo mínimo do direito à dignidade humana, princípio importantíssimo do nosso sistema, escolhido como um dos fundamentos do Estado Democrático de Direito (artigo primeiro, inciso III). Não se pode falar em dignidade da pessoa humana se não está assegurada a utilização da água, quer para beber, quer para sua higiene pessoal. Água, portanto, com utilização regular, é necessária para que se chegue,

\footnotetext{
${ }^{4}$ DELIBERADOR, Giuliano Savioli. Confiança legítima: anatomia de um direito fundamental e suas repercussões junto ao exercício das funções legislativa, administrativa e judiciária. 2013. 80 f. Dissertação (Mestrado em Ciências: área Direito do Estado)- Faculdade de Direito da Universidade de São Paulo, 2013, p. 46.
} 
minimamente, a um conceito de dignidade humana. Não se pode imaginar o conceito de dignidade humana respeitado sem a utilização do ser humano de um pouco de água. ",

Essa visão, que enxerga o acesso à água como elemento componente da noção de direito fundamental, em nível internacional, não é nova, já fazendo parte da agenda da Organização das Nações Unidas (ONU) desde a década de 1960. Usando a pesquisa de Aith e Rothbarth ${ }^{6}$, podemos dizer que o Pacto de Direitos Econômicos, Sociais e Culturais de 1966, que somente viria a ser incorporado pelo Brasil em 1992, já encampava essa visão. Com o passar do tempo, foi sendo aprofundada, tendo ocupado espaços cada vez mais nobres na arena da referida organização internacional, tendo sido a década de 1981 a 1990 declarada como a "Década da Água Potável". Logo em seguida, foi realizada, em Dublin, a Conferência Internacional sobre Água e Meio Ambiente, preparatória para a Rio 92, da qual foram retiradas as bases para o chamado Gerenciamento Integrado de Recursos Hídricos, base das melhores práticas contemporâneas de gestão dos recursos hídricos, que já antes analisamos com maior vagar em obra coletiva sobre o tema, à qual nos reportamos para eventuais aprofundamentos ${ }^{7}$. No mesmo ano, durante a Conferência das Nações Unidas para o Meio Ambiente e Desenvolvimento (RIO 92), surgiu a Agenda 21, conjunto de normas atinentes à construção de modelos sustentáveis de desenvolvimento econômico, cujo Capítulo 18 bebe das fontes da Conferência de Dublin para elencar normas protetivas.

Retomando o papel do direito de acesso à água como direito fundamental, destaquese que a Assembleia Geral das Nações Unidas declarou a água e o saneamento como direitos humanos, condições essenciais para o pleno gozo dos demais direitos tidos como fundamentais (Resolução A/RES/64/292), o que completa, sem sombra de dúvida, o trajeto do direito à água rumo ao nobre rol dos direitos fundamentais.

Diante desse quadro normativo extraído do panorama dos organismos internacionais, a doutrina, mesmo que ainda pouco desenvolvida, vislumbra, sem maiores dificuldades, a

\footnotetext{
${ }^{5}$ ARAÚJO, Luiz Alberto David. A função social da água. In: e algumas implicações nos direitos fundamentais. Bauru: ITE, 2002, p.32. (coord). A tutela da água

${ }^{6}$ AITH, Fernando Mussa Abujamra e ROTHBARTH, Renata. O estatuto jurídico das águas no Brasil. In: UNIVERSIDADE DE SÃO PAULO. INSTITUTO DE ESTUDOS AVANÇADOS. Estudos Avançados, Vol. 29, n. 84, maio/agosto de 2015, p. 164.

${ }^{7}$ DELIBERADOR, Giuliano Savioli. Aprender para não repetir: o gerenciamento integrado de recursos hídricos visto como uma saída da crise. In: CUNHA FILHO, Alexandre Jorge Carneiro; NERY, Ana Rita de Figueiredo e OLIVEIRA, André Tito da Motta (orgs). A crise hídrica e o direito. Racionalidade jurídica a serviço da complexidade socioambiental. Rio de Janeiro: Lumen Juris, 2015, págs. 181-196.
} 
relação entre água e dignidade humana. Ademais, a água guarda um importante aspecto simbólico-cultural, que remonta às mais antigas civilizações, como as mesopotâmicas (localizadas entre os rios Tigre e Eufrates, no Oriente Próximo) e a civilização egípcia, contexto em que é comumente referida como "a dádiva do Nilo". Sobre o tema, bem posta a doutrina de Amorim ${ }^{8}$.

De todo modo, não fosse isso suficiente, a água ainda tem repercussões tamanhas na questão da sustentabilidade de qualquer modelo de desenvolvimento que a ciência do Direito não pode deixar de se debruçar sobre ela. A água é elemento fundamental tanto na conservação de ecossistemas naturais, como nas mais diversas cadeias produtivas, quer seja na agricultura, indústria ou serviços. Daí porque Salati, Lemos e Salati anotam que "Qualquer modificação na oferta natural de água (...) poderá trazer profundas oscilações tanto no equilíbrio dinâmico dos ecossistemas naturais como na produtividade agrícola, com sérias consequências econômicas e sociais"9.

A literatura técnica parece apontar para um consenso no sentido de que um dos maiores desafios para a sustentabilidade da vida humana no planeta Terra é a escassez de água de boa qualidade para suprir as diversas demandas postas pela antropização. Para os autores citados acima, "Sem dúvida nenhuma, entre os fatores que limitam o desenvolvimento sustentável, está a substância fundamental para os processos vitais: a água"10.

Outro elemento fundamental a relacionar a água com o princípio da dignidade humana é a sua íntima e óbvia relação com a saúde. Para além dos sabidos fatos de que todos necessitamos consumir certa quantidade de água todos os dias para sobreviver (falase entre 2 e 3 1/dia) e que nosso corpo é formado por aproximadamente $70 \%$ de água, temos que a relação entre ela e a saúde ultrapassa enormemente essas primeiras constatações. E, nesse sentido, a água encarna como nenhuma outra substância a dualidade remédio-veneno formulada por Paracelso, feliz recordação de Samuel Murgel Branco,

\footnotetext{
${ }^{8}$ AMORIM, João Alberto Alves. Direito das Águas: o regime jurídico da água doce no direito internacional e no direito brasileiro. São Paulo: Lex Editora, 2009, p. 43 e ss.

${ }^{9}$ SALATI, Eneas; LEMOS, Haroldo Mattos de e SALATI, Eneida. Água e o desenvolvimento sustentável. In: REBOUÇAS, Aldo da C.; BRAGA, Benedito e TUNDISI, José Galizia (Orgs). Águas Doces no Brasil: capital ecológico, uso e conservação. $3^{a}$ ed. São Paulo: Escrituras Editorial, 2006.

${ }^{10}$ SALATI, Eneas; LEMOS, Haroldo Mattos de e SALATI, Eneida. Op cit, p. 45.
} 
Sandra Azevedo e José Galizia Tundisi ${ }^{11}$. Até por sua condição de solvente universal, a água é ferramenta essencial de limpeza e assepsia ambiental, ao mesmo tempo em que funciona como o vetor ideal para a disseminação de toda forma de impureza ou agente patogênico. Reconstituindo capítulo fundamental da própria história da ciência, os citados autores afirmam que, embora desde as civilizações mesopotâmicas já se vissem suspeitas nesse sentido, foi apenas a partir de 1876 que os cientistas passaram a enxergar na água o veículo de microrganismos causadores de doenças muitas vezes de alta letalidade. Entretanto, foi apenas a partir do Séc. XX que foram documentados e provados os impactos favoráveis do tratamento das águas distribuídas pelos sistemas públicos de abastecimento. Tanto é assim que, atualmente, há um sólido arcabouço normativo, que remonta à Lei 6.437, de 20 de agosto de 1977, regulação essa hoje consubstanciada na Portaria MS 2.914, de 12 de dezembro de 2011, que dispõe sobre os procedimentos de controle e de vigilância da qualidade da água para consumo humano e seu padrão de potabilidade.

Com relação às patologias associadas de alguma forma à água, Branco, Azevedo e Tundisi as classificam em quatro classes:

a) Doenças com origem na água: cólera, febre tifoide e disenteria;

b) Doenças produzidas por água contaminada a partir de organismos que não se desenvolvem na água: tracoma e leishmaniose;

c) Doenças relacionadas a organismos cujos vetores se desenvolvem na água: malária, fileriose, febre amarela e dengue (aqui ousamos, à luz das recentes epidemias, adicionar as febres zyka e chikungunya);

d) Doenças dispersadas pela água.

Além disso, os autores anotam relatos de correlação entre aumentos de precipitações (chuvas) e epidemias de cólera em países como Congo, Quênia, Bolívia, Honduras e Nicarágua. Da mesma forma, o fenômeno meteorológico El Niño foi relacionado a epidemias de malária na Bolívia, Colômbia, Peru, Equador, Venezuela, Paquistão e Sri Lanka, o que evidencia cabalmente a relação entre o ciclo da água e a saúde humana ${ }^{12}$. No Brasil, em todos os verões, cujas altas temperaturas trazem os maiores índices pluviométricos nas porções territoriais mais populosas do país, assistimos estupefatos a surtos e epidemias de dengue, e agora também

\footnotetext{
${ }^{11}$ BRANCO, Samuel Murgel; AZEVEDO, Sandra M. F. O.; TUNDISI, José Galizia. Água e saúde humana. In: REBOUÇAS, Aldo da C.; BRAGA, Benedito e TUNDISI, José Galizia (Orgs). Águas Doces no Brasil: capital ecológico, uso e conservação. $3^{\mathrm{a}}$ ed. São Paulo: Escrituras Editorial, 2006, p. 248.

${ }^{12}$ BRANCO, Samuel Murgel; AZEVEDO, Sandra M. F. O.; TUNDISI, José Galizia. Op cit, p. 252.
} 
chikungunya e zyka, inclusive levando a Organização Mundial de Saúde a decretar emergência sanitária mundial no início de 2016, seguindo a declaração de mesma natureza feita, em âmbito nacional, pelo Ministério da Saúde em novembro de 2015.

E, por fim, para além da questão da veiculação de doenças, fenômenos naturais associados à água impactam a vida humana de forma absolutamente dramática. Sax, Thompson Jr, Leshy e Abrams relatam que inundações matam 10 vezes mais pessoas nos Estados Unidos que qualquer outra espécie de desastre natural, trazendo também prejuízos materiais da ordem de bilhões de dólares todos os anos ${ }^{13}$.

Outro uso absolutamente fundamental da água (e aqui se destaca a sua "mutação" em recurso hídrico, por incorporar a noção de aproveitamento econômico da água) é a agropecuária. Em primeiro lugar, fundamental anotar que segundo dados do Centro de Estudos Avançados em Economia Aplicada (CEPEA) da Escola Superior de Agricultura Luiz de Queiroz (ESALQ) da Universidade de São Paulo, o agronegócio respondeu em 2013 por aproximadamente $22,5 \%$ do Produto Interno Bruto brasileiro ${ }^{14}$. O Relatório de Conjuntura dos Recursos Hídricos da Agência Nacional de Águas para 2013, sustentado em dados da FAO (ONU), apresenta o Brasil como o quarto país do mundo em potencial para irrigação, estimando, para 2012, a área brasileira irrigada em 5,8 milhões de hectares, anotando que, em relação à área plantada total, o peso das áreas irrigadas quadruplicou desde $1970^{15}$. Entre os usos múltiplos possíveis dos recursos hídricos, o setor agropecuário tem se mantido como o maior consumidor de recursos hídricos no Brasil, como se vê no gráfico abaixo, extraída do citado relatório conjuntural da ANA, que calcula em $84 \%$ a participação do setor no consumo de recursos hídricos em 2013/14 ${ }^{16}$ :

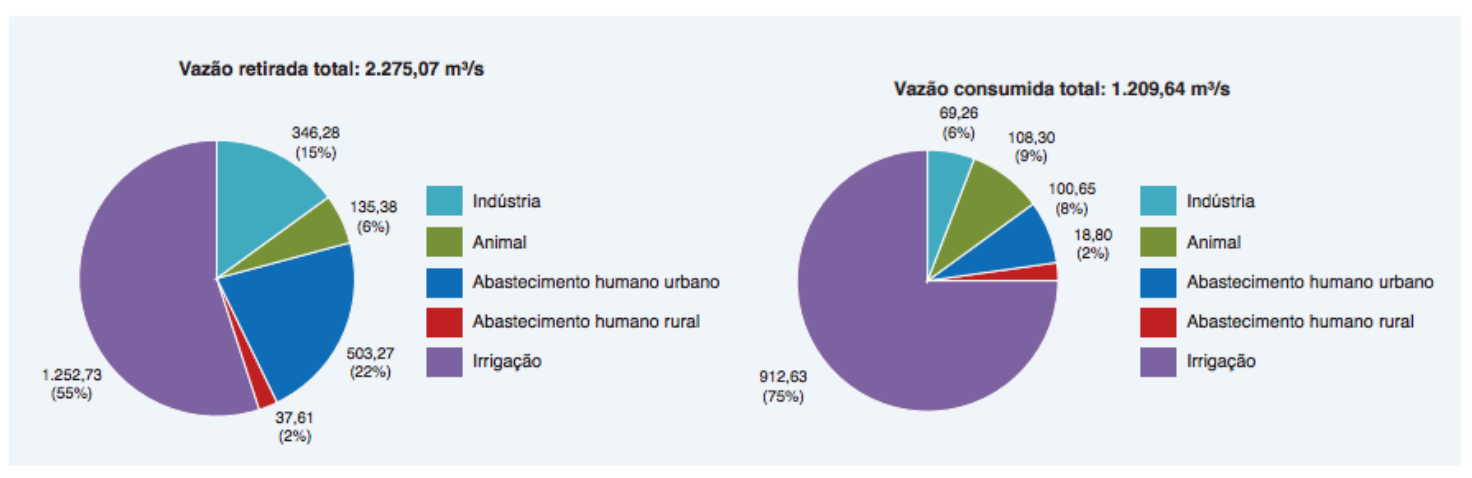

Figura 1: Vazões de retirada totais (captada e consumida) no Brasil $\left(\mathrm{m}^{3} / \mathrm{s}\right)$

\footnotetext{
${ }^{13}$ SAX, Joseph L.; THOMPSON Jr, Barton H.; LESHY, JOHN D. e ABRAMS, Robert H. Legal Control of Water Resources: Cases and Materials. Saint Paul, MN: Thomson West, 2006, p. 10.

${ }^{14}$ CEPEA-USP. PIB do agronegócio. Disponível em <http://cepea.esalq.usp.br/pib/>. Acesso em 4 de junho de 2015.

${ }^{15}$ AGÊNCIA NACIONAL DE ẢGUAS. Conjuntura dos recursos hídricos: informe 2015 / Agência Nacional de Águas. - Brasília: ANA, 2015, p. 36.

${ }^{16}$ AGÊNCIA NACIONAL DE ÁGUAS. $\boldsymbol{O}$ p $\boldsymbol{c i t}$, p. 89.
} 
São muitas as razões para se irrigar uma cultura, todas redundando no aumento da produtividade. Telles e Domingues enumeram, ao lado de razões próprias a determinadas culturas, a possibilidade de produção em áreas de déficit hídrico, na entressafra e com incremento na qualidade do produto $^{17}$. Com relação à pecuária, por evidente o recurso hídrico é fundamental para a dessedentação de animais (uso, aliás, no mesmo patamar de prioridade do abastecimento público à luz da Lei 9.433/97), demanda essa que se exacerba no contexto da produção intensiva. Nesse diapasão, não apenas a dessedentação consome o recurso hídrico, mas também chuveiros e outros mecanismos de limpeza e controle sanitário, além de instrumentos de controle de temperatura, com demandas totais apresentadas por Telles e Domingues entre $50 \mathrm{~L} /$ dia para bovinos e outros animais de grande porte, como bubalinos e equinos, a $10 \mathrm{~L} /$ dia para ovinos e caprinos. Tudo isso leva a totalizar, para 2010, conforme a tabela acima, $6 \%$ da retirada e $11 \%$ do consumo total de recursos hídricos no Brasil. A garantia de vazões perenes, na qualidade e quantidade necessárias, para atendimento das demandas do agronegócio é, assim, medida de dramática importância para o crescimento econômico brasileiro.

Mas não é apenas no setor primário da economia que a água assume enorme valor econômico e se transmuta em recurso hídrico. Se esse recurso é fundamental no setor agropecuário, não é menos importante no setor industrial. Conforme a figura já apresentada, o uso industrial se apresenta como o terceiro mais intenso no Brasil, perdendo apenas para o setor primário (agropecuária) e para o uso urbano.

$\mathrm{Na}$ indústria, o uso do recurso hídrico se mostra altamente plural. Seja como reagente, matéria prima, solvente de todo tipo de substância, para lavagem de gases e sólidos ou como agente de controle de temperatura, a água se mostra presente nos processos produtivos de qualquer cadeia industrial ${ }^{18}$. O relatório conjuntural da ANA, ao mostrar o predomínio das outorgas concedidas para uso industrial nas regiões hidrográficas do Paraná, do Atlântico Sudeste e do São Francisco, em particular na sua porção meridional (cabeceiras), acaba traçando um retrato da industrialização brasileira, atribuindo esse predomínio ao fato de que nas mesmas regiões se concentram a disponibilidade de mão de obra qualificada, de infraestrutura de transporte a viabilizar o

\footnotetext{
${ }^{17}$ TELLES, Dirceu d'Alkmin e DOMINGUES, Antônio Félix. Água na agricultura e na pecuária. In: REBOUÇAS, Aldo da C.; BRAGA, Benedito e TUNDISI, José Galizia (Orgs). Águas Doces no Brasil: capital ecológico, uso e conservação. $3^{\text {a }}$ ed. São Paulo: Escrituras Editoral, 2006, p. 326.

${ }^{18}$ SILVA, Gil Anderi e KULAY, Luiz Alexandre. Água na indústria. In: REBOUÇAS, Aldo da C.; BRAGA, Benedito e TUNDISI, José Galizia (Orgs). Águas Doces no Brasil: capital ecológico, uso e conservação. $3^{\mathrm{a}}$ ed. São Paulo: Escrituras Editoral, 2006, p. 367.
} 
escoamento da produção e o mercado consumidor dessa produção. A figura abaixo, extraída da peça conjuntural da agência reguladora ${ }^{19}$, ilustra essa concentração:

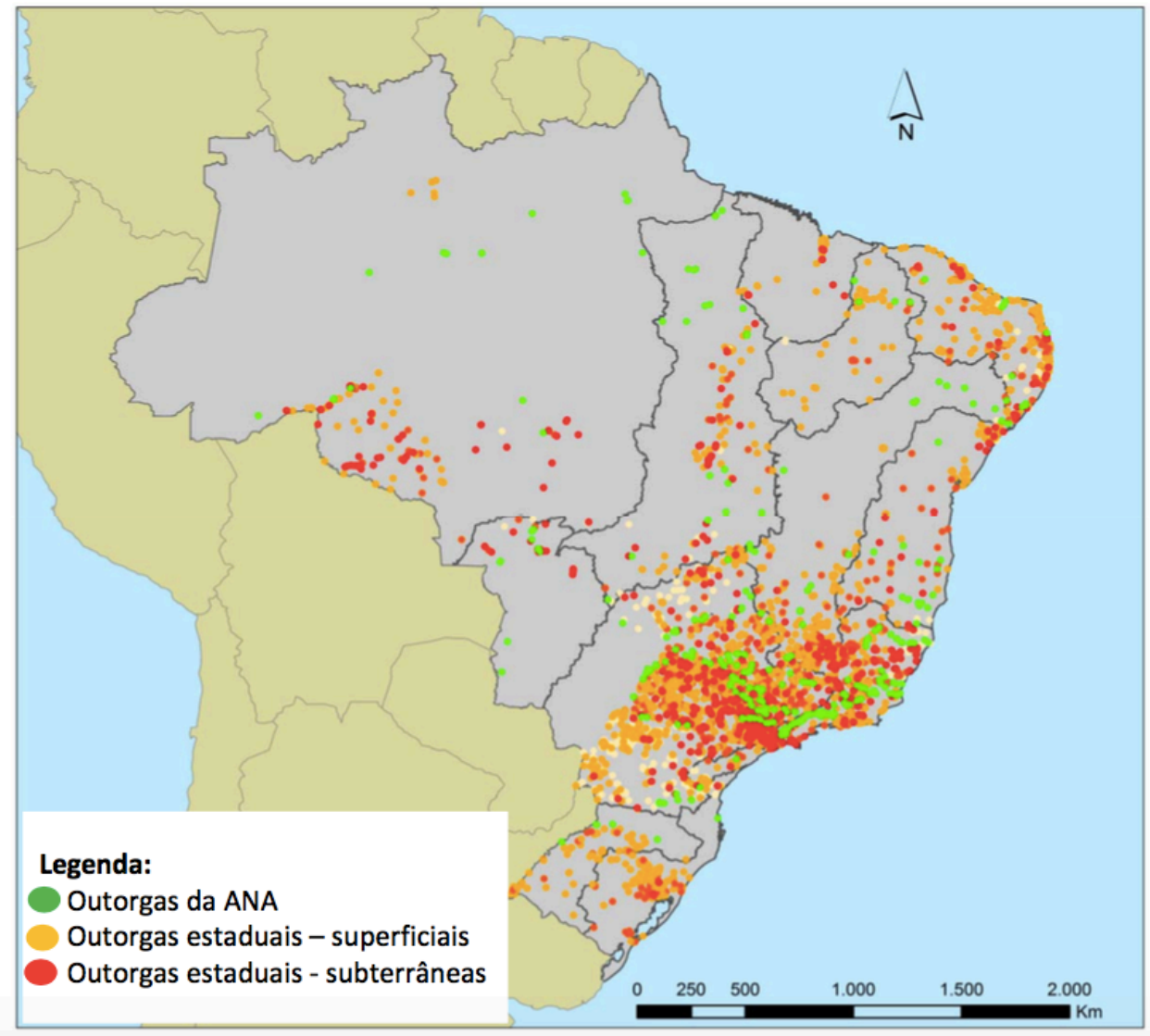

Figura 2: Outorgas de recursos hídricos para uso industrial

O ponto mais interessante em relação ao uso industrial é que este se mostra extremamente sensível a variações na qualidade da água. Muitas cadeias produtivas chegam a exigir padrões qualitativos superiores àqueles exigidos pelo abastecimento público e o consumo humano, impondo a necessidade de diversos tratamentos antes de sua utilização na produção ${ }^{20}$.

Uma vez finda a sua utilização no ambiente industrial, a questão passa a ser o subproduto desse processo. Nos termos colocados por Silva e Kulay,

"O segmento industrial gera, em todo o mundo, milhões de toneladas de rejeitos na forma de efluentes líquidos a cada ano. A procedência desses despejos é decorrente de perdas inerentes ao processamento de insumos, da geração de rejeitos indesejáveis, de ações de manutenção, da fabricação de produtos fora da especificação e eventualmente até de incidentes industriais.

\footnotetext{
${ }^{19}$ AGÊNCIA NACIONAL DE ÁGUAS. $\boldsymbol{o} \boldsymbol{p}$ cit, p. 118.

${ }^{20}$ SILVA, Gil Anderi e KULAY, Luiz Alexandre. Op cit, p. 373.
} 


\begin{abstract}
A disposição desses contaminantes provoca alterações diversas nos corpos receptores desses despejos, todas elas resultando em impactos ambientais significativos. Além disso, a presença de impurezas em fontes potenciais de fornecimento de água impõe custos adicionais de tratamento para que esse bem possa ser reaproveitado em quaisquer atividades". (grifo nosso)
\end{abstract}

Assim, o uso industrial é sem dúvida um dos que exige maior atenção do sistema jurídico, na medida em que é fundamental que se garanta a sustentabilidade do uso, o que naturalmente impõe a necessidade do estabelecimento de padrões rigorosos a garantir a prevenção da poluição dos cursos d'água por rejeitos industriais, mormente porque, nos dizeres de Dione Mari Morita,
"Em se tratando de águas residuárias contendo poluentes perigosos, o impacto negativo não se limita à área onde está instalada a indústria, fonte desses efluentes, mas pode abranger o sistema de coleta e transporte de esgoto sanitário e a estação de tratamento, patrimônios da sociedade, se a concessionária de saneamento os receber. Os poluentes podem, ainda, exigir um tratamento adicional nas fases líquida e sólida, porém é injusto que este custo recaia sobre toda a sociedade. Da mesma forma, não é correto que a população arque com os custos da reabilitação de áreas contaminadas abandonadas pelas indústrias geradoras de tais contaminantes". ${ }^{21}$

Outro uso potencial da água é a produção de energia elétrica- a chamada hidroeletricidade. Trata-se de uso da mais alta relevância para o caso brasileiro, apontado consensualmente por autores como Cid Tomanik Pompeu ${ }^{22}$ como a linha mestra da normatividade brasileira do direito de águas na primeira metade do Séc. XX, é a produção de energia elétrica, a chamada hidroeletricidade. Se Kelman et al afirmam que, no mundo, a hidroeletricidade responde por $25 \%$ da geração total de energia elétrica ${ }^{23}$, a Agência

\footnotetext{
${ }^{21}$ MORITA, Dione Mari. Prevenção e controle da poluição da água e do solo causadas por resíduos industriais perigosos. $527 \mathrm{f}$. Tese (Livre Docência em Engenharia Hidráulica e Sanitária)- Escola Politécnica, Universidade de São Paulo, 2010, p. 1.

${ }^{22}$ POMPEU, Cid Tomanik. Direito de Águas no Brasil. São Paulo: Editora Revista dos Tribunais, 2010, p. 138.

${ }^{23}$ KELMAN, Jerson at al. Hidreletricidade. In: REBOUÇAS, Aldo da C.; BRAGA, Benedito e TUNDISI, José Galizia (Orgs). Águas Doces no Brasil: capital ecológico, uso e conservação. $3^{\mathrm{a}}$ ed. São Paulo: Escrituras Editoral, 2006, p. 508.
} 
Nacional de Energia Elétrica apresentava a hidroeletricidade como responsável pela geração de dois terços da energia elétrica brasileira, conforme se vê na figura abaixo ${ }^{24}$ :

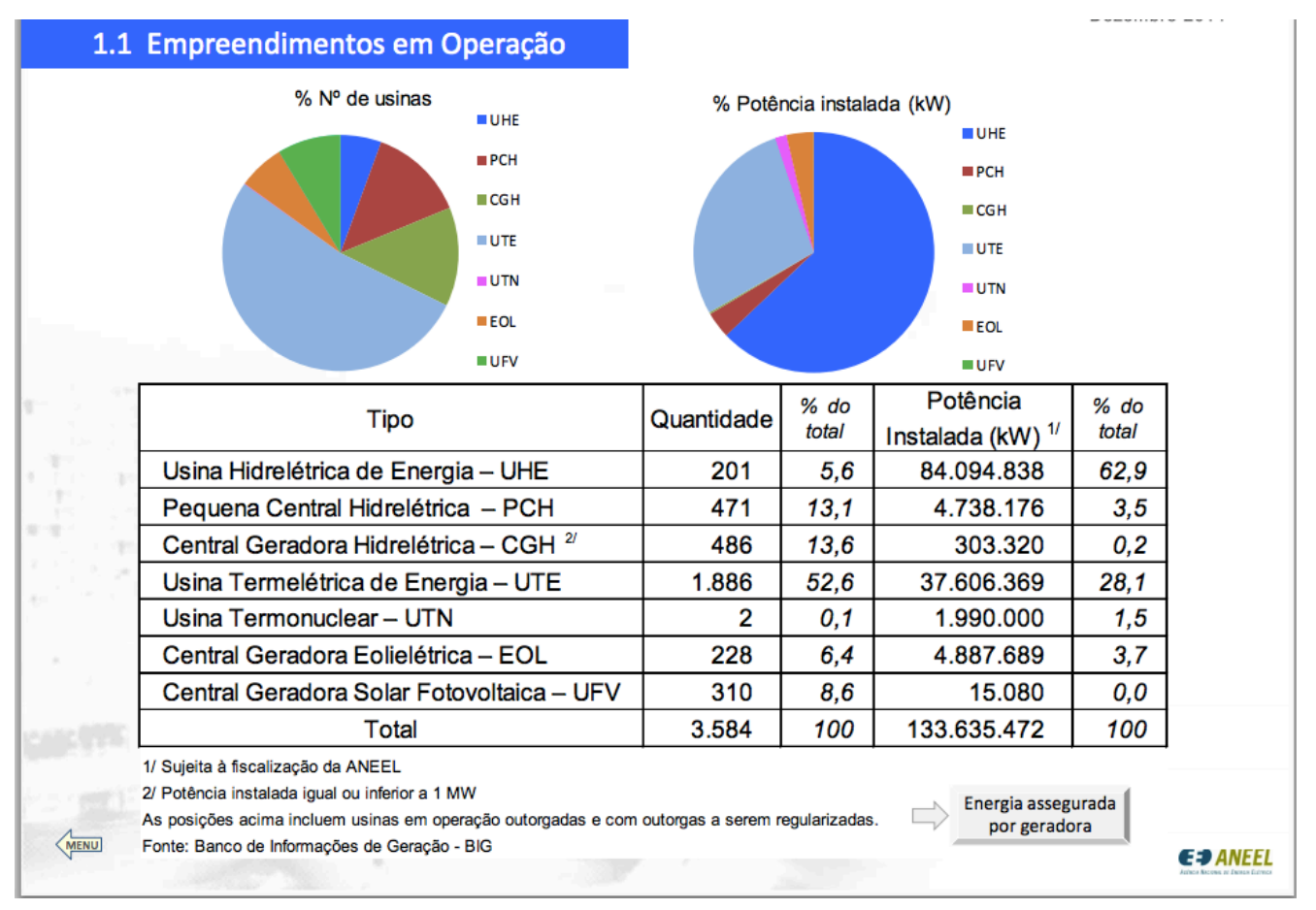

Figura 3: Matriz energética brasileira (Dez. 2014)

Essa modalidade de geração de energia apresenta como grande vantagem o fato de que se trata de energia renovável, não tendo seu estoque global deplecionado pelo uso, como ocorre com as fontes minerais de energia. Ademais, não gera gases com efeito estufa, como ocorre, por exemplo, com termoelétricas abastecidas a carvão ou óleo diesel, estando isenta de contribuição ao aquecimento global ${ }^{25}$. Pela mesma razão, tem custo de geração mais baixo do que a alternativa termoelétrica, pois não necessita de "combustível", conforme a lição de Kelman et al.

Se a crise de abastecimento de água pela qual passaram, muito recentemente, os estados do sul-sudeste do Brasil fez todos se lembrarem de que é quase impossível viver sem água nas torneiras, a ideia de um desabastecimento de tamanha dimensão no setor elétrico não parece apresentar perspectivas mais animadoras. Não é necessário aqui discutir com maior vagar a essencialidade do serviço de energia elétrica no contexto atual.

${ }^{24}$ AGÊNCIA NACIONAL DE ENERGIA ELÉTRICA. Informações Gerencias: Dezembro 2014. Disponível em <http://www.aneel.gov.br/arquivos/PDF/Z_IG_Dez_2014_v3.pdf $>$. Acesso em 07 de junho de 2015.

${ }^{25}$ AGÊNCIA NACIONAL DE ENERGIA ELÉTRICA. Atlas da Energia Elétrica no Brasil. Brasília: ANEEL, 2008, p. 53. 
Os diversos problemas e questões colocados ao setor hídrico pelo amplo uso dos potenciais hidroelétricos para gerar a energia de que o país precisa estão entre os mais intensos dilemas enfrentados na gestão de recursos hídricos no Brasil. Para lembrar alguns desses problemas e questões, destacam-se o uso múltiplo e a garantia de disponibilidade hídrica para geração de energia, a cobrança pelo uso da águam a segurança das barragens, a viabilidade ambiental de grandes reservatórios e a transposição de bacias para atendimento às demandas do setor elétrico. A prática inclusive mostra que a convivência entre ambos os setores (elétrico e hídrico) não é das mais harmoniosas. Nesse sentido, outra obra de Kelman traz relatos muito interessantes dos conflitos travados cotidianamente nessa arena ${ }^{26}$.

Enfim, feitas essas considerações, percebemos que o tema aqui tratado nada tem de simples ou pouco importante. Ao contrário, trata-se de um tema transversal, da mais alta complexidade, presente no cotidiano de toda a população brasileira e mundial, demandando atenção da ciência jurídica, especialmente a nacional, a merecer um enfoque interdisciplinar, o que se pretendeu contemplar por meio de ampla consulta a literatura acadêmica não jurídica neste trabalho.

${ }^{26}$ KELMAN, Jerson. Desafios do Regulador. Rio de Janeiro: Synergia/CEE-FGV, 2009. 


\section{CONSIDERAÇÕES FINAIS}

Com o fito de melhor esclarecer as conclusões a que chegou este trabalho, este capítulo final apresenta um breve relato do trajeto por ele percorrido, destacando os pontos essenciais a cada tema analisado.

1) A água é fator imprescindível para a vida e fator de produção obrigatório em qualquer cadeia produtiva. Nesse sentido, exige do Estado um cuidado extraordinário, de modo a garantir sua disponibilidade quali-quantitativa para as futuras gerações. Em um Estado organizado sob a forma federativa, como é o Brasil, assume particular relevo a forma como a interação entre os diversos entes federados se reflete na gestão desse recurso natural.

2) $\mathrm{O}$ direito já reconheceu a íntima relação entre o acesso à água e a dignidade humana. Esse reconhecimento vem expresso na Convenção Americana de Direitos Humanos, Pacto de San Jose da Costa Rica, ratificado pelo Brasil em 1992. No plano global, a Resolução A/RES/64/292 da Assembleia Geral da Organização das Nações Unidas reconhece o acesso à água potável como direito fundamental da pessoa humana.

3) Nos dias atuais, a literatura técnica vê a escassez de água de qualidade como um dos maiores desafios à sustentabilidade da vida humana. Isso porque guarda íntima relação com a saúde, seja porque o consumo regular de água é condição para a vida, seja porque diversas doenças são contraídas por consumo de água contaminada. Da mesma forma, há fontes que indicam que inundações são a principal causa de morte por desastre natural nos Estados Unidos.

4) A água tem, ainda, papéis fundamentais em todos os processos produtivos da economia contemporânea, a exemplo da agropecuária (responsável por mais de $80 \%$ do volume de água consumido no Brasil), da indústria (terceiro maior uso no Brasil) e da geração de energia elétrica $(25 \%$ da energia elétrica mundial é gerada a partir da exploração de potenciais hidroelétricos- no Brasil, esse número chega a 70\%).

5) Entre as diversas formas de organização estatal presentes na contemporaneidade, destacam-se o Unitarismo, o Federalismo e outras tipologias de transição, como o Estado Autonômico Espanhol e o Estado Regional Italiano. Na realidade, o que diferencia cada uma delas é o grau de autonomia que é conferido aos entes periféricos em detrimento do 
ente governamental central. Ela é nula no Estado Unitário e vai se aprofundando até chegar ao Estado Federal.

6) Sendo o federalismo o foco deste trabalho, um primeiro esforço seria conceituar o termo. Entretanto, dada a diversidade dos arranjos federais contemporâneos, esse seria um esforço inútil. Assim, mais produtivo é identificar as características diagnósticodiferenciais do Estado Federal para, assim, conhecê-lo.

7) Em que pese a doutrina registrar antecedentes do federalismo desde os tempos bíblicos, é no período da independência dos Estados Unidos que suas características atuais foram sedimentadas. Foi a repulsa ao centralismo da metrópole que forjou o ambiente propício para o desenvolvimento da ideia de federalismo, que, etimologicamente, remete a pacto (do latim, foedus).

8) A ideia central do federalismo clássico é a garantia de autonomia a unidades subnacionais que abrem mão de sua soberania para formar o Estado Federal. Diante da inegável aptidão dessa forma de Estado para acomodar a diversidade, vivemos hoje o chamado "espetáculo da federalização", em que a adesão ao federalismo vem se tornando uma constante ao redor do mundo. Entretanto, na visão deste trabalho, é a flexibilidade do modelo federalista e sua ampla capacidade de adaptação que o tornam uma verdadeira coqueluche entre os Estados nacionais contemporâneos.

9) Entre as características que definem o federalismo, temos as capacidades de autogoverno, autoadministração, auto-organização e autolegislação. Também temos a repartição de rendas e competências entre os entes federados, a indissolubilidade da federação como traços comuns a todos os Estados federados do mundo. Outro elemento relevante é o Bicameralismo, com a Câmara Alta funcionando como um lócus de representação dos entes federados, em que pese tenha a pesquisa localizado federações que prescindem deste elemento.

10) A despeito da existência dessas características mais ou menos uniformes entre os diversos Estados Federais do mundo, é verdade que o federalismo assume uma diversidade de modelos, chegando a doutrina a falar em arranjos federais. O primeiro deles é o federalismo clássico, típico dos primeiros dias do federalismo norte-americano, também chamado de federalismo dual. Nele coexistem esferas paralelas de governo que mantém-se afastadas entre si. Circunstâncias históricas, em particular a crise econômica de 1929, 
demonstraram a inconveniência desse modelo, passando a exigir uma ação concertada entre os diversos entes federados.

11) Feita esta constatação, a doutrina aponta para dois modelos distintos de federalismo. $O$ primeiro é o federalismo de integração, aplicado no panorama nacional no regime que se seguiu aos acontecimentos de março/abril de 1964. A despeito de se pretender uma espécie de federalismo, a doutrina reconhece nele pesados traços de centralismo, o que leva diversos autores a vê-lo mais como um instrumento autoritário do que propriamente uma real alternativa federalista, no qual predomina o ente central em detrimento dos entes periféricos.

12) Em oposição ao federalismo de integração, a doutrina identifica o federalismo de cooperação. Tendo por principal marca a descentralização, este modelo demanda e induz uma forte cooperação entre os entes federados. Essa cooperação se manifesta na prestação conjunta de serviços públicos e numa atuação governamental simbiótica. Um ente atua ao lado do outro, e não mais paralelamente.

13) Essa cooperação, embora orgânica, não é voluntária. Ao contrário, ela deriva de um dever que decorre da própria adoção do federalismo, cujas balizas são estabelecidas sob o primado da Constituição. Sob esse primado, no federalismo de cooperação os entes regionais atuam na formação da vontade geral e executam como tarefa própria. Há uma permeabilidade entre os diversos entes que diferencia esta variante do federalismo de suas demais correlatas.

14) Esse dever de cooperação tem por fundamento uma norma principiológica implícita à Constituição, reconhecida pela jurisprudência da Corte Constitucional alemã, chamada de Bundestreue. Esse princípio, também conhecido por Princípio da Lealdade Federativa, foi originalmente formulado na doutrina nos primeiros anos do Séc. XX, sendo posteriormente reconhecido, já em 1952, pelo mais alto Tribunal da República Federal da Alemanha, passando a ser constantemente visitado por ele.

15) Embora gestado na Alemanha, este trabalho conclui, em linha com a melhor doutrina sobre o assunto, que o princípio da Lealdade Federativa tem plena aplicação no Brasil sob o primado da Constituição Federal de 1988. Isso pode ser constatado pela análise de diversos institutos presentes no cotidiano do constitucionalismo nacional. 
16) Considerando ser a água um recurso finito e dotado de valor econômico, seu uso desde sempre foi objeto de regulação jurídica. Nessa trajetória o Direito de Águas se afirma como disciplina jurídica própria, dotada de fontes, regras e princípios que lhe são peculiares. Uma de suas grandes especificidades é ter o seu âmbito de aplicação dado por um recurso natural, por óbvio, a água.

17) O Direito de Águas se afirma como disciplina a partir da experiência histórica nos Estados Unidos. Ali, floresceu enquanto se processava a ocupação dos territórios a Oeste daquele país, diante dos conflitos que existiam por conta da severa escassez de água da região. Tratou-se de um desenvolvimento casuístico, que desembocou em dois grandes sistemas que até hoje convivem no panorama norte-americano e servem como inspiração para quase a totalidade dos demais Estados nacionais.

18) O primeiro sistema é o da Apropriação Primária (Prior Appropriation). Nele, o direito de uso de uma determinada vazão incumbe a quem a reclamou primeiro. Essa concepção, fortemente associada às atividades mineradoras da região Oeste do Estados Unidos, ainda vigora em numeroso conjunto de estados daquele país, especialmente aqueles com maior incidência de territórios áridos. O sistema não condiciona o direito à apropriação de vazões à posse de terreno lindeiro ao recurso hídrico objeto da captação, mas sim, com algumas mitigações específicas, à demonstração da real intenção de uso da água, a efetiva captação ou desvio da água de seu curso original e a utilização para fins que cumpram sua função social, trazendo algum tipo de benefício à coletividade. Na ocorrência de escassez, prevalecem os usos mais antigos (seniors) em relação aos usos mais novos (juniors).

19) O segundo sistema é o chamado Riparianismo (Riparian Rights), típico do Leste dos Estados Unidos e do panorama britânico. Seu traço característico é o privilégio conferido ao proprietário do terreno lindeiro ao curso d'água no que se refere ao direito de uso dessa água. Tem um caráter mais protetivo em relação às vazões e, no seu trajeto histórico, acabou privilegiando usos não consuntivos, como a produção de energia. Com o passar do tempo, incorporou a busca de harmonia entre os diversos usos como uma de suas pedras de toque, privilegiando os chamados reasonable uses. Esses usos conferem prerrogativas aos seus titulares, variando no tempo e no espaço, conforme fatores econômicos, políticos ou culturais. Com o crescimento das cidades, a doutrina do riparianismo foi forçada a evoluir, de modo a permitir que as cidade pudessem captar águas para uso público independentemente da eventual propriedade de terrenos lindeiros aos cursos d'água. 
20) No Brasil, o direito de águas esteve historicamente atrelado ao direito civil, tendo, sob o regime do Código de Águas de 1934, um olhar fortemente voltado para a produção de energia elétrica. Na nossa tradição constitucional, em um primeiro momento histórico, a água não era um tema tratado em nível da Carta Magna, vigorando as Leis coloniais que não colidiam com a Ordem Constitucional Imperial. Na primeira Constituição Republicana, dada a não atribuição à União das competências para regular a questão hídrica, elas restaram conferidas aos Estados. O uso das águas era livre, sendo apenas condicionado à propriedade das terras lindeiras.

21) A Constituição de 1934 inovou profundamente no tratamento do tema. Pela primeira vez, foi atribuída à União a competência para legislar sobre águas e energia elétrica. Inovou também ao atribuir à União a dominialidade sobre "os lagos e quaisquer correntes em terrenos do seu domínio ou que banhem mais de um Estado, sirvam de limites com outros países ou se estendam a território estrangeiro; " (art. 20, II). Tendo vida curta, essa ordem constitucional cedeu lugar àquela de 1937, outorgada, que concentrou na União as competências atinentes à questão hídrica, condicionando mesmo a competência suplementar dos Estados à autorização federal, mantendo inalterado o regime de dominialidade.

22) Com a redemocratização, surge a Constituição de 1946, que inova ao incorporar o federalismo cooperativo ao constitucionalismo brasileiro. Nela, permaneciam os Estados com a competência supletiva em matéria de águas, que ordinariamente incumbia à União. Essa ordem não teve vida longa, posto que, após os acontecimentos de março/abril de 1964, foi outorgada a Constituição de 1967. Na realidade, o Regime Militar manteve o regramento anterior. Da mesma forma, a Emenda Constitucional 01, de 1969, que trouxe na realidade uma nova Constituição, não inovou no tratamento da questão hídrica. Entretanto, convém lembrar que, à época, vigorava o Federalismo de Integração, que mitigava qualquer iniciativa de autonomia dos entes federados.

23) Finalmente, em 1988, é promulgada a atual Constituição da República Federativa do Brasil. No que toca à dominialidade, a atual Carta Política suprimiu a existência de águas privadas ou municipais, tornando todas as águas brasileiras bens públicos, de domínio estadual ou federal, conforme o caso. No trato da questão das competências, à União cabe legislar privativamente sobre água, comportando, entretanto, normativa estadual 
fundamentada na capacidade de autoadministração dos bens pertencentes aos entes federados.

24)Esse quadro é complementado por uma extensa normativa infraconstitucional. Essa normativa estabelece a estrutura do Sistema Nacional de Gestão de Recursos Hídricos (SNGRH), a quem cumpre implementar a Política Nacional de Recursos Hídricos, tendo como órgãos a Agência Nacional de Águas (ANA), os Conselhos de Recursos Hídricos, Comitês de Bacia, Agências de Águas e demais órgãos estaduais, federais e municipais cujas competências se relacionem com a gestão de recursos hídricos, com as competências que lhes são próprias.

25) Para a gestão dos recursos hídricos, a Lei $9.433 / 97$ elenca uma série de instrumentos, todos estruturados a partir do reconhecimento da bacia hidrográfica como unidade básica de gestão. Justamente por isso, o primeiro instrumento é justamente o Plano de Bacia Hidrográfica, que revela uma decisão fundamental, democraticamente gestada, ao direcionar o uso dos recursos hídricos para determinadas finalidades, priorizando certos usos em detrimento de outros. Importante anotar que, embora não seja Lei em sentido estrito, o Plano de Bacia integra o bloco de legalidade e assim deve condicionar a gestão do uso e ocupação do solo de modo a catalisar uma gestão sustentável dos recursos hídricos em ambiente rural e urbano.

26) O segundo instrumento é o enquadramento de corpos d'água. Trata-se em verdade de um instrumento de classificação dos corpos d'água, para adequar os usos de suas águas à qualidade que eles demandam. Assim, mesmo um uso inevitavelmente poluidor é admitido em pontos específicos da bacia, evitando a degradação por ele provocada se transfira a outros pontos nos quais se promovem usos mais exigentes. É uma forma, portanto, de se alocar, de maneira mais racional, cargas poluidoras.

27) Vistos os principais instrumentos de planejamento, passamos a ver os instrumentos de controle do uso. Em outras palavras, tratamos do exercício do Poder de Polícia dos recursos hídricos. O principal desses instrumentos é a outorga do direito de uso. Partindo do pressuposto de que as águas são bens públicos de uso comum do povo, representa o ato pelo qual o ente que exerça domínio sobre o recurso hídrico permite ao interessado um uso anormal do bem público. Tem por finalidade assegurar o controle quali-quantitativo dos usos de recursos hídricos. 
28) Estão sujeitas à outorga quaisquer interferências que possam alterar de alguma forma o ciclo natural da água, em sua qualidade ou sua quantidade. Apenas usos que, por seu diminuto impacto possam ser tidos por insignificantes, ficam isentos de outorga, independentemente se o uso pretendido é consuntivo ou não.

29) É tormentoso o debate acerca da natureza jurídica do ato de outorga. Em que pese a existência de determinação legal no sentido de que o ato tem natureza de autorização administrativa de uso, a doutrina aponta uma série de características do ato que colidem com o instituto da autorização, a exemplo do fato de que as outorgas são deferidas por tempo determinado, na forma da Lei, o que contraria a precariedade típica do ato autorizativo, que, em regra, produz seus efeitos por tempo indeterminado, sujeito a revogação com fundamento no interesse público. Nesse sentido, parece melhor enquadrálo como ato típico do exercício do Poder de Polícia do Estado, mas uma figura sui generis do Direito Administrativo brasileiro. Em outras palavras, trata-se de um ato administrativo que se enquadra em uma categoria diferente de todos os demais.

30) Prestigiando os chamados Dublin Principles do Gerenciamento Integrado de Recursos Hídricos, temos, na cobrança pelo uso de recursos hídricos, o próximo instrumento de gestão. Tem por finalidade promover o uso racional da água, por meio do reconhecimento de seu valor econômico, bem como angariar recursos para o financiamento de programas e intervenções contemplados nos planos de recursos hídricos. Esses recursos, uma vez arrecadados, têm natureza de receita pública originária, estando sujeitos à aplicação obrigatória nas finalidades elencadas na Lei 9.433/97. A cobrança deve ter como principais parâmetros a quantidade de água captada, as características dos seus resíduos e o consumo efetivo de água. Todo uso outorgável se sujeita à exigência de cobrança.

31) Por fim, o último instrumento previsto na Lei $9.433 / 97$ é o Sistema Nacional de Informações sobre Recursos Hídricos. Trata-se de um sistema alimentado pelos órgãos que integram o Sistema Nacional de Gerenciamento de Recursos Hídricos, gerido pela Agência Nacional de Águas, que congrega informações sobre a gestão de recursos hídricos no Brasil.

32) A título de conclusão, reafirmamos que a gestão de recursos hídricos se sujeita ao dever de cooperação entre os entes federados derivado do princípio do Bundestreue. As três condições apontadas na doutrina para a incidência desse dever (co-titularidade da 
atribuição da gestão dos recursos hídricos, interesse comum e necessidade de uniformização) estão plenamente atendidas. Entendemos que a ação cooperativa dos entes federados se dará sob o marco das competências comuns elencadas, precipuamente, no art. 23 da Constituição da República Federativa do Brasil, que, embora não traga a gestão de recursos hídricos textualmente elencada no rol de seus incisos, permite a extração dessa competência através de simples exercício hermenêutico sistêmico do teor desses incisos.

Fundamental esclarecer que este trabalho identifica que o dever de cooperação em matéria de gestão de recursos hídricos decorre da própria adoção do federalismo cooperativo como forma de Estado da República Federativa do Brasil. Desse modo, entendemos que a Lei Complementar de que trata o parágrafo único do art. 23 da Constituição Federal não é, de maneira nenhuma, condição para a existência desse dever e para a sujeição de toda e qualquer pessoa política aos seus postulados. É nesse regime constitucional que, na nossa visão, deverão se pautar as condutas do Poder Público acerca da questão daqui para a frente, modernizando o tratamento do tema e alinhando-o às melhores práticas de gestão de recursos hídricos conhecidas no panorama internacional. 


\section{BIBLIOGRAFIA}

AGÊNCIA NACIONAL DE ÁGUAS. Conjuntura dos Recursos Hídricos no Brasil: 2013. Brasília: ANA, 2013.

Brasília: ANA, 2015.

Conjuntura dos recursos hídricos: informe 2015.

AGÊNCIA NACIONAL DE ENERGIA ELÉTRICA. Informações Gerenciais:

Dezembro 2014. Disponível em <http://www.aneel.gov.br/arquivos/ PDF/Z_IG_Dez_2014_v3.pdf $>$. Acesso em 07 de junho de 2015.

Brasil. Brasília: ANEEL, 2008.

Atlas da Energia Elétrica no

AITH, Fernando Mussa Abujamra e ROTHBARTH, Renata. O estatuto jurídico das águas no Brasil. In: UNIVERSIDADE DE SÃO PAULO. INSTITUTO DE ESTUDOS AVANÇADOS. Estudos Avançados, Vol. 29, n. 84, maio/agosto de 2015, p. 163-177.

ALMEIDA, Fernanda Dias Menezes de. Competências na Constituição de 1998. São Paulo: Atlas, 2007.

AMORIM, João Alberto Alves. Direito das Águas: o regime jurídico da água doce no direito internacional e no direito brasileiro. São Paulo: Lex Editora, 2009.

ANSELMO, José Roberto. O papel do Supremo Tribunal Federal na concretização do federalismo brasileiro. Tese (Doutorado em Direito). Faculdade de Direito da PUC-SP, 2006.

ARAÚJO, Caetano Ernesto Pereira de. O bicameralismo na Constituição de 1988. In: DANTAS, Bruno; CRUXÊN, Eliane; SANTOS, Fernando; LAGO, Gustavo Ponce de Leon (Orgs.). Constituição de 1988. O Brasil 20 anos depois. Brasília: Senado Federal, 2008, v. II, p. 331-345.

ARAÚJO, Luiz Alberto David \& NUNES JÚNIOR, Vidal Serrano. Curso de Direito Constitucional. 7. ed. São Paulo: Saraiva, 2007.

ARAÚJO, Luiz Alberto David. Características comuns do Federalismo. In: BASTOS, Celso (coord). Por uma nova Federação. São Paulo: Revista dos Tribunais, 1995.

A função social da água. In: (coord). A

tutela da água e algumas implicações nos direitos fundamentais. Bauru: ITE, 2002

BANDEIRA DE MELLO, Osvaldo Aranha. Natureza Jurídica do Estado Federal. São Paulo: Prefeitura do Município de São Paulo, 1948.

BARACHO, José Alfredo de Oliveira. Teoria geral do federalismo. Belo Horizonte: FUMARC/ UCMG, 1982.

BARROS, Sérgio Rezende de. Variantes do federalismo na Europa: o Estado Regional Italiano. In: CAGGIANO, Monica Herman Salem e RANIERI, Nina Beatriz Stocco (orgs). As Novas Fonteiras do Federalismo. São Paulo: Imprensa Oficial, 2008. 
BARROSO, Luis Roberto. Interpretação e aplicação da Constituição: fundamentos de uma dogmática constitucional transformadora. São Paulo: Saraiva, 1996.

Água: a próxima crise. In: Temas

de Direito Constitucional II. Rio de Janeiro: Renovar, 2002, p. 265-272.

Curso de Direito Constitucional contemporâneo. São Paulo:

Saraiva, 2009.

BARTH, Flávio Terra. Aspectos Institucionais do gerenciamento de recursos hídricos. In: REBOUÇAS, Aldo da C.; BRAGA, Benedito e TUNDISI, José Galizia (Orgs). Águas Doces no Brasil: capital ecológico, uso e conservação. $3^{\mathrm{a}}$ ed. São Paulo: Escrituras Editoral, 2006.

BASSANI, Luigi Marco. Liberty, State and Union: The Political Theory of Thomas Jefferson. Macon, GA: Mercer University Press, 2010.

BASTOS, Celso. Por uma nova federação. São Paulo: Revista dos Tribunais, 1995.

BERCOVICI, Gilberto. Dilemas do Estado Federal brasileiro. Porto Alegre: Livraria do Advogado, 2004.

Federalismo Cooperativo nos Estados Unidos e no Brasil. In:

Revista da Procuradoria Geral do Município de Porto Alegre, Porto Alegre, v. 16, p. 13-25, 2002.

BONAVIDES, Paulo. O papel dos organismos regionais no federalismo brasileiro. In: Revista de finanças públicas, ano XLIV, no. 358, abr/jun, 1984.

BRANCO, Samuel Murgel; AZEVEDO, Sandra M. F. O.; TUNDISI, José Galizia. Água e saúde humana. In: REBOUÇAS, Aldo da C.; BRAGA, Benedito e TUNDISI, José Galizia (Orgs). Águas Doces no Brasil: capital ecológico, uso e conservação. $3^{\mathrm{a}}$ ed. São Paulo: Escrituras Editoral, 2006.

BRAND, Dirk. Financial constitutional law: A comparison between Germany and South Africa. Johannesburg: Konrad-Adenauer-Stiftung, 2006.

BRETON, Albert e FRASCHINI, Angela. Is Italy a Federal or even a Quasi-Federal State? In: POLIS Working Papers, Universitá del Piemonte Orientale "Amedeu Avogadro", Alessandria, n. 234, Março de 2016.

BULOS, Uadi Lammêgo. Curso de Direito Constitucional. São Paulo: Saraiva, 2014.

BUZAID, Alfredo. O Estado federal brasileiro. Brasília: Ministério da Justiça, 1971.

CAGgianO, Monica Herman Salem e RANIERI, Nina Beatriz Stocco (orgs). As Novas Fronteiras do Federalismo. São Paulo: Imprensa Oficial, 2008.

CAGGIANO, Monica Herman Salem. O Princípio Federativo e a Segurança Jurídica. In: CAGGIANO, Monica Herman Salem e RANIERI, Nina (orgs). As Novas Fronteiras do Federalismo. São Paulo: Imprensa Oficial do Estado de São Paulo, 2008.

Manole, 2004.

Direito Parlamentar e Direito Eleitoral. Barueri: 
CANotillo, J. J. Gomes. Direito Constitucional e Teoria da Constituição. Lisboa: Almedina, 1999.

CAPONERA, Dante A. Principles of water law and administration: national and international. Leiden: Taylor and Francis, 2007.

CARAZZA, Roque Antonio. O princípio federativo, a lealdade federativa, a guerra scal e os repasses das quotas nanceiras constitucionalmente devidas às pessoas políticas, mormente aos municípios. In: Revista da Procuradoria da Câmara Municipal de São Paulo, v.3, n.1, jan/dez de 2014.

CARVAlHO, Matheus. Manual de Direito Administrativo. Salvador: Ed. Juspodivm, 2015.

CASSUTO, David N. e SAMPAIO, Romulo S.R.. Water Law in the United States and Brazil: Climate Change \& Two Approaches to Emerging Water Poverty. In: William and Mary Law and Policy Review, Vol. 35: 371, 2010-2011.

CEPEA-USP. PIB do agronegócio. Disponível em <http://cepea.esalq.usp.br/pib/>. Acesso em 4 de junho de 2015.

CHOUDHRY, Sujit e STACEY, Richard. Independent or Dependent? Constitutional Courts in Divided Societies. In: HARVEY, Colin e SCHWARTZ, Alexander (eds). Rights in Divided Societies. Portland: Hart Publishing, 2012, págs. 87-122.

CÔRTES, Lara Barbosa Quadros. Estado Federal e igualdade na educação básica pública. Tese (Doutorado). Faculdade de Direito da Universidade de São Paulo, São Paulo, 2013.

CORWIN, Edward. S (ed). The Constitution of the United States of America. Analysis and Interpretation. Annotations of cases decided by the Supreme Court of the United States to June 30, 1952. Washington D.C.: United States Government Printing Office, 1953.

CUNHA FILHO, Alexandre Jorge Carneiro da. Poder de polícia: compreensão contemporânea do instituto e discussão sobre a possibilidade de delegação de seu exercício a entes privados. Ribeirão Preto: IELD, 2014.

O poder de polícia da água: reflexões

sobre medidas extremas à disposição do poder público para assegurar a ordem hídrica. In: CUNHA FILHO, Alexandre Jorge Carneiro; NERY, Ana Rita de Figueiredo e OLIVEIRA, André Tito da Motta (orgs). A crise hídrica e o direito. Racionalidade jurídica a serviço da complexidade socioambiental. Rio de Janeiro: Lumen Juris, 2015, p. 225-257.

CURRIE, David P. The Constitution of the Federal Republic of Germany. Chicago: The Chicago University Press, 1994.

DALLARI, Dalmo de Abreu. Elementos de Teoria Geral do Estado. São Paulo, Saraiva, 2001.

. O Estado Federal. São Paulo: Ática, 1986.

DELIBERADOR, Giuliano Savioli. Confiança legítima: anatomia de um direito fundamental e suas repercussões junto ao exercício das funções legislativa, administrativa 
e judiciária. 2013. 80 f. Dissertação (Mestrado em Ciências: área Direito do Estado)Faculdade de Direito da Universidade de São Paulo, São Paulo, 2013.

- Saneamento e Direito Urbanístico: Aproximações.

Revista dos Tribunais São Paulo: RTSP, v. 2, n. 5-6, p. 47-70, mar.-abr./ maio-jun. 2014.

Aprender para não repetir: o gerenciamento integrado de recursos hídricos visto como uma saída da crise. In: CUNHA FILHO, Alexandre Jorge Carneiro; NERY, Ana Rita de Figueiredo e OLIVEIRA, André Tito da Motta (orgs). A crise hídrica e o direito. Racionalidade jurídica a serviço da complexidade socioambiental. Rio de Janeiro: Lumen Juris, 2015.

DINAN, John. Patterns of subnational constitutionalism in federal countries. In: Rutgers Law Journal, Newark, NJ, v. 39, p. 837-861.

ELAZAR, Daniel J. Exploring Federalism. Tuscaloosa and London: The University of Alabama Press, 1991.

ENTERRÍA, Eduardo García de. El proyecto de Constitución Europea. In: Revista Española de Derecho Constitucional, n ${ }^{\circ} 45$, set/dez. 1995.

FERRERI, Janice Helena. A organicidade das práticas intergovernamentais na Federação canadense como contribuição à Federação brasileira. Tese (Doutorado em Direito). Faculdade de Direito da Pontifícia Universidade Católica de São Paulo, 1999.

FELIX, Érika Pereira e CARDOSO, Arnaldo Alves. Fatores ambientais que afetam a precipitação úmida. Química Nova na Escola, no 21, maio de 2005, p. 47-50. Disponível em $<$ http:// qnesc.sbq.org.br/online/>. Acesso em 3 de setembro de 2013.

FERREIRA, Pinto. Curso de Direito Constitucional. 12. ed. São Paulo: Saraiva, 2002.

FERREIRA FILHO, Manoel Gonçalves. Temas de Direito Constitucional Estadual e questões sobre o pacto federativo. São Paulo: ALESP, 2004.

. O Federalismo no Brasil. In: CAGGIANO, Monica Herman Salem e RANIERI, Nina Beatriz Stocco (orgs). As Novas Fonteiras do Federalismo. São Paulo: Imprensa Oficial, 2008.

FERREIRA FILHO, Manoel Gonçalves. O Estado Federal Brasileiro. Revista da Faculdade de Direito da Universidade de São Paulo, São Paulo, v. 77, p. 136-137, 1982.

FIGUEIREDO, Lúcia Valle. Competências administrativas dos Estados e Municípios. In: Revista de Direito Administrativo, no. 207. Rio de janeiro: Renovar, jan/mar de 1997.

FIGUEIREDO, Marcelo. O Saneamento Básico e o Direito- uma visão dos principais problemas jurídicos. In: WAGNER JR., Luiz Guilherme da Costa (coord). Direito Público: estudos em homenagem ao Professor Adilson de Abreu Dallari. Belo Horizonte: Del Rey, 2004.

FRANCO, Afonso Arinos de Melo. Curso de Direito Constitucional Brasileiro. Vol. I. São Paulo: Revista Forense, 1968. 
FREITAS, Vladimir Passos de (coord). Águas- aspectos jurídicos e ambientais. Curitiba: Juruá, 2010.

GANZIERA, Maria Luiza Machado. Direito de Águas: Disciplina jurídica das águas doces. São Paulo: Atlas, 2006.

GAZZANIGA, Jean-Louis. Droit de l'eau. Paris: Librairies Techniques, 1979.

GETCHES, David H. Water Law in a nutshell. St. Paul, MN: Thomson/Reuters, 2009.

GILLILAN, David M. e BROWN, Thomas C. Instream Flow Protection: seeking a balance in western water use. Washington D.C.: The Island Press, 1997.

HABERMAS, Jürgen. Direito e democracia: entre facticidade e validade. Rio de Janeiro: Tempo Brasileiro, 2003.

HAMILTON, Alexander; MADISON, James; JAY, John. O Federalista. Belo Horizonte: Líder, 2003.

HAMON, Francis; TROPER, Michel e BORDEAU, Georges. Direito Constitucional. Barueri: Manole, 2005.

HESSE, Konrad. Elementos de Direito Constitucional da República Federal da Alemanha. Porto Alegre: SAFE, 1998.

HORTA, Raul Machado. A Autonomia do Estado-Membro no Direito Constitucional Brasileiro. Belo Horizonte: 1964.

JUSTEN FILHO, Marçal. Parecer sobre o Projeto de Lei $\mathbf{n}^{\mathbf{0}} \mathbf{3 . 8 8 4} / \mathbf{2 0 0 4}$. Disponível em $<$ www. cidades.gov.br/media/consorciopublico/parecermarcaljustenfilho $>$. Acesso em 8 de fevereiro de 2015.

KATZ, Ellis. Aspectos Constitucionais e políticos do Federalismo americano. In: Revista de Direito Público, ano XVI, nº 65, São Paulo: Revista dos tribunais, jan/mar de 1983.

- American Federalism and the Challenges of the modern world. In: CAGGIANO, Monica Herman Salem e RANIERI, Nina Beatriz Stocco (orgs). As Novas Fonteiras do Federalismo. São Paulo: Imprensa Oficial, 2008.

KELMAN, Jerson. Desafios do Regulador. Rio de Janeiro: Synergia/CEE-FGV, 2009.

KELMAN, Jerson at al. Hidreletricidade. In: REBOUÇAS, Aldo da C.; BRAGA, Benedito e TUNDISI, José Galizia (Orgs). Águas Doces no Brasil: capital ecológico, uso e conservação. $3^{\mathrm{a}}$ ed. São Paulo: Escrituras Editoral, 2006.

KOMMERS, Donald P. The Constitutional Jurisprudence of the Federal Republic of Germany. Durham and London: Duke University Press, 1997.

KYMLICKA, Will. Federalism and Secession: At Home and Abroad. In: Canadian Journal of Law and Jurisprudence, London, Ontario, Vol. 13, No. 2, pp. 207-224, jul de 2000 . 
KUBLISCKAS, Wellington Márcio. Cooperação interfederativa: instrumentos para a efetividade da lealdade federativa na Constituição Federal de 1988. Tese de doutorado. São Paulo: Fac. de Direito da Universidade de São Paulo, 2012.

LAMARÃO, Patrícia. O Princípio da lealdade federativa como cláusula geral nas relações federativas. In: Consulex: Revista Jurídica, vol. 14, n. 326, 2010.

LEN, Christopher L. Synthesis - A brand new Water Law. In: University of Denver Water Law Review, Vol. 55, n. 8, Outono de 2004, p. 55-92.

LEONCY, Leo Ferreira. Apreciação do RDC pelo Supremo deverá considerar a lealdade federativa. Disponível em $<$ http://www.conjur.com.br/2014-nov15/observatorio-constitucional-supremo-devera-considerar-lealdade-federativa-apreciarrdc?pagina $=3>$. Acesso em 27 out. 2016.

MASSICOTE, Louis. Legislative Unicameralism: A Global Survey and a Few Case Studies. In: The Journal of Legislative Studies, Vol. 7, $1^{\text {a }}$ Ed., 2001, p. 151-170.

MEDAUAR, Odete. Direito Administrativo Moderno. São Paulo: Ed. Revista dos Tribunais, 2010.

MENDES, Gilmar Ferreira e BRANCO, Paulo Gustavo Gonet. Curso de Direito Constitucional. São Paulo, Saraiva, 2014.

MENDES, Ludmilson Abritta. Análise dos critérios de outorga de direito de usos consuntivos dos recursos hídricos baseados em vazões mínimas de permanência. Dissertação (Mestrado em Engenharia). Escola Politécnica da Universidade de São Paulo, 2007.

MELO, André Luiz Dantas. A Reestruturação dos Municípios Sergipanos com Base na sua Viabilidade Econômico-Financeira. Disponível em $<$ http://www.esaf.fazenda.gov.br/assuntos/premios/premios-1/premios-2015/xx-premiotesouro-nacional-2015-pagina-principal/monografias-premiadas-xx-premio-tesouronacional-2015/tema-2-2o-lugar-andre-luis-d-melo>. Acesso em 22 de mar de 2016

MINISTÉRIO DA FAZENDA. Secretaria da Receita Federal do Brasil. Carga Tributária no Brasil - 2014 (Análise por Tributo e Bases de Incidência). Brasília: MF/SRFB, 2015.

MINISTÉRIO DO MEIO AMBIENTE. Secretaria de Recursos Hídricos. Plano Nacional de Recursos Hídricos. Panorama e estado dos recursos hídricos do Brasil. Vols. 1 e 2. Brasília: MMA, 2006.

MORAES, Alexandre de. Direito Constitucional. São Paulo: Atlas, 2014.

MORAES, Guilherme Peña de. Tipos de Estado Federal. In: RAMOS, Dircêo Torrecillas. O Federalista Atual: Teoria do Federalismo. Belo Horizonte: Arraes Editores, 2013, pp. 108-120.

MORITA, Dione Mari. Prevenção e controle da poluição da água e do solo causadas por resíduos industriais perigosos. 527 f. Tese (Livre Docência em Engenharia Hidráulica e Sanitária)- Escola Politécnica, Universidade de São Paulo, 2010.

NERY JR., Nelson; NERY, Rosa Maria de Andrade. Constituição Federal comentada e legislação constitucional. São Paulo: Editora Revista dos Tribunais, 2006. 
ORGANIZAÇÃO PARA COOPERAÇÃO E DESENVOLVIMENTO ECONÔMICO. Governança dos Recursos Hídricos no Brasil. Paris: OECD Publishing, 2015.

PAINTER, Martin. Collaborative Federalism. Economic reform in Australia in the 1990s. Melbourne: Cambridge University Press, 1998.

PEREIRA, Fábio Franco. A Federação no Constitucionalismo Brasileiro. Dissertação (Mestrado em Direito do Estado). Faculdade de Direito da Universidade de São Paulo, 2010 .

POMPEU, Cid Tomanik. Direito de Águas no Brasil. São Paulo: Editora Revista dos Tribunais, 2010.

RAMOS, Dircêo Torrecillas. O Federalismo assimétrico. São Paulo: Plêiade, 1998.

RANIERI, Nina Beatriz Stocco. Teoria do Estado: do Estado de Direito ao Estado Democrático de Direito. Barueri: Manole, 2013.

REBOUÇAS, Aldo da C., BRAGA, Benedito e TUNDISI, José Galizia (Orgs). Águas Doces no Brasil: capital ecológico, uso e conservação. $3^{\mathrm{a}}$ ed. São Paulo: Escrituras Editoral, 2006.

REBOUÇAS, Aldo da C. Água doce no mundo e no Brasil. In: REBOUÇAS, Aldo da C., BRAGA, Benedito e TUNDISI, José Galizia (Orgs). Águas Doces no Brasil: capital ecológico, uso e conservação. $3^{\mathrm{a}}$ ed. São Paulo: Escrituras Editoral, 2006.

RIBAS MAURA, Andres. Notas sobre el Estado Regional de la Constitucion Italiana de 1947. In: Cuadernos de la Facultad de Derecho de la Universitat de les Illes Balears, Palma de Mallorca, núm. 16, p. 297-313, 1987-1988.

RIBEIRO, José. Propriedade das Águas e o Registro de Imóveis. In: FREITAS, Vladimir Passos de. Águas: aspectos jurídicos e ambientais. Curitiba: Juruá, 2010.

ROCHA, Carlos Vasconcelos. Federalismo: dilemas de uma definição conceitual. Civitas, Porto Alegre, v.11, n. 2, p.323-338, maio/ago. 2011.

ROVIRA, Enoch Alberti. Federalismo y cooperación en la Republica Federal Alemana. Madri: Centro de Estudios Constitucionales, 1986.

SALATI, Eneas; LEMOS, Haroldo Mattos de e SALATI, Eneida. Água e o desenvolvimento sustentável. In: REBOUÇAS, Aldo da C.; BRAGA, Benedito e TUNDISI, José Galizia (Orgs). Águas Doces no Brasil: capital ecológico, uso e conservação. $3^{\mathrm{a}}$ ed. São Paulo: Escrituras Editoral, 2006.

SANTOS, Aloysio Vilarino. Federalismo do Séc. XXI: Paradigmas e Desafios. O redesenho do Estado Brasileiro. Tese (Doutorado em Direito). Faculdade de Direito da PUC-SP, 2009.

SAX, Joseph L.; THOMPSON Jr, Barton H.; LESHY, John D. e ABRAMS, Robert H. Legal Control of Water Resources: Cases and Materials. Saint Paul, MN: Thomson West, 2006.

SCHWARTZ, Bernard. O Federalismo norte-americano atual. Rio de Janeiro: Forense, 1984. 
SENISE, Irineia Maria Braz Pereira. Formação de Estados Federados. Dissertação (Mestrado em Direito do Estado). Faculdade de Direito da Universidade de São Paulo, 2011.

SERRA, Silvia Helena. O Tratamento Constitucional das Águas Minerais. Tese (Doutorado em Direito). Faculdade de Direito da USP, 2007.

SILVA, Gil Anderi e KULAY, Luiz Alexandre. Água na indústria. In: REBOUÇAS, Aldo da C.; BRAGA, Benedito e TUNDISI, José Galizia (Orgs). Águas Doces no Brasil: capital ecológico, uso e conservação. $3^{\mathrm{a}}$ ed. São Paulo: Escrituras Editoral, 2006.

SILVA, José Afonso da. Curso de Direito Constitucional Positivo. São Paulo: Malheiros, 2010.

Direito ambiental constitucional. São Paulo: Malheiros, 1994.

SILVA, Virgílio Afonso da. Federalismo e articulação de competências no Brasil. In: PETERS, Guy e PIERRE, Jon (org). Administração Pública. São Paulo: EdUnesp, 2010.

SOLANES, Miguel e GOZALEZ-VILlareAL, Fernando. The Dublin Principles for Water as Reflected in a Comparative Assessment of Institutional and Legal Arrangements for Integrated Water Resources Management. Disponível em $<$ http://www.gwp.org/Global/ToolBox/Publications/Background\%20papers/03\%20The\%2 0Dublin $\% 20$ Principles $\% 20$ for $\% 20$ Water $\% 20$ as $\% 20$ reflected $\% 20 \mathrm{in} \% 20 \mathrm{a} \% 20$ Comparatice $\% 20$ Assessment $\% 20$ of $\% 20$ Institutional $\% 20$ and $\% 20$ Legal $\% 20$ Arrangements $\% 20$ for $\% 20$ I WRM\%20(1999).pdf>. Acesso em 11 de julho de 2016.

SOLOZÁBAL ETCHEVARRÍA, José Juan. Sobre el Estado Autonómico Español. In: Revista de estudios políticos, ISSN 0048-7694, No 78, 1992, págs. 105-130.

SUNSTEIN, Cass R. Constitutionalism and Secession. In: University of Chicago Law Review, Chicago, Vol. 58, No. 2, p. 633-670, primavera de 1991.

TARLOCK, A. Dan; CORBRIDGE Jr., James N.; GETCHES, David H.; BENSON, Reed D. Water Resource Management: a casebook in Law and Public Policy. New York: Thomson Reuters/Foundation Press, 2009.

TAVARES, Ana Lúcia de Lyra. Contribuição do Direito Comparado às fontes do Direito Brasileiro. Prisma Jurídico, São Paulo, v. 5, p. 59-77, 2006.

TELLES, Dirceu d'Alkmin e DOMINGUES, Antônio Félix. Água na agricultura e na pecuária. In: REBOUÇAS, Aldo da C.; BRAGA, Benedito e TUNDISI, José Galizia (Orgs). Águas Doces no Brasil: capital ecológico, uso e conservação. $3^{\mathrm{a}}$ ed. São Paulo: Escrituras Editoral, 2006.

THOMPSON Jr., Barton; LESHY, John D.; ABRAMS, Robert H. Legal Control of Water Resources: Cases and Materials. West, 2012.

WATTS, Ronald L. Comparing Federal Systems. Montreal: McGill-Queen's University Press, 2008.

WIEL, Samuel C. Theories of Water Law. In: Harvard Law Review, Cambridge, MA, Vol. 27, No. 6, pp. 530-544, abr de 1914.

ZIMMERMAN, Augusto Cotta. Teoria Geral do Federalismo Democrático. Rio de Janeiro: Ed. Lumen Juris, 2005. 